\title{
Quality Changes after Oven-drying and Frozen Storage of Bluestripe Herring (Herklotsichthys quadrimaculatus)
}

\author{
Wen Chieh Sung*, Mindia Haryono \\ Department of Food Science, National Taiwan Ocean University, Keelung, Taiwan \\ *Corresponding author: sungwill@mail.ntou.edu.tw
}

\begin{abstract}
Proximate composition (moisture, ash, protein, and fat) of muscle tissue and small, medium, and large sizes bluestripe herring (Herklotsichthys quadrimaculatus) were analyzed. The fresh index of all three sizes bluestripe herring was monitored every month during six months frozen storage $\left(-20^{\circ} \mathrm{C}\right)$. Small-sized specimens spoil faster than the larger ones; therefore it is mostly processed into dried products right away and sold in the market in dried form. As two of the often-used methods, oven and sun drying of small bluestripe herring were compared for their water activity and moisture changes, freshness index values ( $\mathrm{pH}$, Thiobarbituric acid (TBA), and Total volatile basic nitrogen (TVBN)), and overall acceptability. $\mathrm{pH}$ and TVBN values indicate that bluestripe herring (all sizes) are still under fresh index value in fresh condition even after 6 month storage at $-20^{\circ} \mathrm{C}$, but considering the TBA values, the fish are considered best to consume when fresh or at most before 1 month at $-20^{\circ} \mathrm{C}$ frozen storage. The fish oven-dried at $80^{\circ} \mathrm{C}$ gave lower TVBN amount than sun dried fish, and both values are still considered suitable for human consumption. Their $\mathrm{pH}, \mathrm{TVBN}$ and TBA values showed significant difference. The fish oven dried at $60^{\circ} \mathrm{C}$ and $80^{\circ} \mathrm{C}$ received a higher score by panelists than sun-dried fish. Oven drying at $80^{\circ} \mathrm{C}$ can be an alternative to traditional sun drying as it is time saving. Frozen storage still considered as the best method for mitigating quality changes of bluestripe herring.
\end{abstract}

Keywords: Bluestripe herring, oven drying, frozen storage

Cite This Article: Wen Chieh Sung, and Mindia Haryono, "Quality Changes after Oven-drying and Frozen Storage of Bluestripe Herring (Herklotsichthys quadrimaculatus)." Journal of Food and Nutrition Research, vol. 5, no. 12 (2017): 935-940. doi: 10.12691/jfnr-5-12-9.

\section{Introduction}

Bluestripe herring (Herklotsichthys quadrimaculatus) is a member of Clupeidae family abundantly found in Pacific area, including Philippines [1]. Despite of the high nutritional value most small pelagic clupeid fish (about $90 \%$ ) are mainly used as fish meal [2]. Small-fatty fish like herrings do not have a long shelf-life, even when chilled. Determining the freshness and shelf-life is important for product management [3]. Small bluestripe herring spoils very fast. To prevent spoilage, it is mostly processed and sold as dried products. Traditionally, small fish are sun-dried but this method can have hygienic problems and is highly depended on the weather [4]. Drying in open air during the rainy season also poses a high risk to microbial spoilage and insect exposure [3]. Oven drying may solve the problem. However, higher temperatures are often used potentially affecting the quality of the dried product [4]. Therefore, further studies are needed to optimize and analyze the effects of the drying process which may be species-specific.

The aim of the present study was to analyze and compare the results of two drying processes for various size classes of the small-sized bluestripe herring: (a) oven and (b) sun in terms of freshness and quality during frozen storage at $-20^{\circ} \mathrm{C}$ in order to assess the safety limits of such products for human consumption.

\section{Materials and Methods}

\subsection{Materials}

In 2014 fish were sampled in May (total weight was 10 $\mathrm{kg}$; size range $=1$ to $13 \mathrm{~g}$; traditional brimstone fishing method: the fishman uses huge fire light to attract bluestripe herring in the night) and October (50 kg; size range above $14 \mathrm{~g}$; obtained by drag netting method) in Jinshan, New Taipei City, Taiwan.

The first batch of bluestripe herring sample caught in May 2014 was frozen in blocks, delivered within one week after the catch, and sorted to 2 different sizes; small (S), and medium (M) without thawing. The small fish was weighed around 1-4 g while the medium was 5-13 g. The second batch caught in October 2014 was weighed around 14 grams or more and categorized as Large (L) fish. Samples were stored in $-20^{\circ} \mathrm{C}$ (Frigidaire Frost free, NC, USA) until analysis.

\subsection{Composition of caught Bluestripe Herring}

Analysis of moisture, protein (micro-Kjeldahl), fat, and ash content was undertaken by using AOAC [5] method. Analysis of calcium content was done by Aquatic Products Inspection Centre at Aquaculture Department of 
National Taiwan Ocean University. The digested solution was properly diluted using sub-boiled distilled water and analyzed for the concentrations of calcium using inductively coupled plasma mass spectrophotometry (ICP MS)(Thermo X-series 2, Texas city, TX, USA) [5].

\subsection{Freshness Index Analysis during Frozen Storage}

pH measurement. $100 \mathrm{~g}$ of fish was taken randomly, minced with 12 speed osterizer blender (Oster, FL, USA) then $3 \mathrm{~g}$ was homogenized in (ACE-AM3) homogenizer

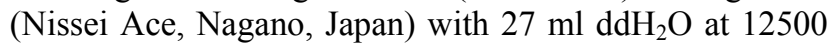
rpm for $3 \mathrm{~min}$. The suspension was used to determine the $\mathrm{pH}$ (Mettler-Toledo MP-220, Columbus, OH, USA) at room temperature.

TVBN Determination. TVBN (Total volatile basic nitrogen) values were determined using method from Cobb et al. [6] with a slight modification. $5 \mathrm{~g}$ of minced fish was homogenized with $20-30 \mathrm{ml}$ TCA $7 \%$ at 12500 rpm for 3 minutes. The supernatant was filtered, adjusted to $100 \mathrm{ml}$, and kept in $4^{\circ} \mathrm{C}$ prior to use. Conway dish was filled with $1 \mathrm{ml}$ boric acid reagent $(10 \mathrm{~g}$ boric acid, $200 \mathrm{ml}$ $95 \%$ ethanol, $5 \mathrm{ml} 0.03 \%$ bromocresol green, and $5 \mathrm{ml}$ $0.06 \%$ methyl red in $1 \mathrm{~L}$ solution). Saturated $\mathrm{K}_{2} \mathrm{CO}_{3}$ was reacted to sample and incubated for $2 \mathrm{~h}$ in tightly-sealed Conway dish. The boric acid reagent was titrated with 0.1 $\mathrm{N} \mathrm{HCl}$ until the color returned to pink as it was in the blank dish. The TVBN value was measured according to the formula below:

$\operatorname{TVBN}(\mathrm{mg} / 100 \mathrm{ml})=0.1 \times 14 \times \frac{(A-B)}{1000} \times F \times \frac{100}{W} \times 100 \%$

$\mathrm{A}=$ amount of $0.1 \mathrm{~N} \mathrm{HCl}$ used to titrate the sample $(\mu \mathrm{l})$

$\mathrm{B}=$ amount of $0.1 \mathrm{~N} \mathrm{HCl}$ used to titrate the blank $(\mu \mathrm{l})$

$\mathrm{F}=$ factor of $0.1 \mathrm{~N} \mathrm{HCl}$

$100 / \mathrm{W}=$ dilution of sample weight $(\mathrm{g})$ in $100 \mathrm{ml}$ TCA

$1.4=$ equivalent amount of nitrogen $(\mathrm{mg})$ in $1 \mathrm{ml} \mathrm{HCl}$ $0.1 \mathrm{~N}$

TBA Determination. The TBA (Thiobarbituric acid) analysis method was modified from Vyncke [7] and Konosu et al. [8]. $5 \mathrm{~g}$ minced fish was added with $20 \mathrm{ml}$ TCA 7\% and homogenized in homogenizer (ACE-AM3, Nissei Ace, Nagano, Japan) at $12500 \mathrm{rpm}$ for $3 \mathrm{~min}$. The suspension was centrifuged at $2264 \times \mathrm{g}, 4^{\circ} \mathrm{C}$ for $20 \mathrm{~min}$ in refrigerated centrifuge (CF 7D2, Hitachi, Tokyo, Japan). The steps above were repeated 3 times and the resulting supernatants were pooled, filtered through No. 1 Whatman filter paper (Advantec MFS, Inc., Dublin, CA, USA), and adjusted to $50 \mathrm{ml}$ volume with TCA $7 \%$. $2 \mathrm{ml}$ of the filtrate was then mixed with $2 \mathrm{ml}$ of $0.02 \mathrm{M}$ thiobarbituric acid reagent and boiled for $30 \mathrm{~min}$. The absorbance was measured after cooled down at $532 \mathrm{~nm}$ (C-1800MK-II, Tokyo Denshoku CO., LTD, Tokyo, Japan). 1,1,3,3 tetraethoxypropane (TEP) is used to make the standard curve at concentrations from $0.01-1.8 \mathrm{ppm}$.

\subsection{Drying of Small Fish Pre-Frozen After Capture}

Around $1 \mathrm{~kg}$ of small-sized fish (1-4 g each fish) was boiled directly (without thawing) into $10 \mathrm{~L}$ of $2 \%$ salt solution for 5 minutes. The water was then removed and the fish were drained for $5 \mathrm{~min}$ at room temperature. After that, the fish (300 $\mathrm{g}$ each group) were arranged on aluminum tray and dried in open air for 42 hours, in $60^{\circ} \mathrm{C}$ oven for $14 \mathrm{~h}$, and in $80^{\circ} \mathrm{C}$ oven for 10 hours (Yihdern DK-500, LMI Co., Ltd., Taipei, Taiwan).

Determination of water activity $\left(a_{w}\right)$ and moisture content. 20 grams of sample was taken every $2 \mathrm{~h}$ (for $60^{\circ} \mathrm{C}$ and $80^{\circ} \mathrm{C}$ oven dry method) and $6 \mathrm{~h}$ (for sun dry method) then grinded with blender. $3 \mathrm{~g}$ of the powder was used for $a_{w}$ measurement with Aqualab CX-2 (Decagon Devices, Inc., WA, USA). The remaining powdered sample was used for moisture content analysis using AOAC [5] method as described before.

Freshness index analysis of dried fish. The freshness parameters used for dried small fish are $\mathrm{pH}, \mathrm{TVBN}$, and TBA analysis. All parameters were analyzed with the same methods used in $\mathrm{pH}, \mathrm{TVBN}$, and TBA analysis of frozen raw fish described above. The fresh limit of TVBN value for fatty fish is $20 \mathrm{mg} \mathrm{N} / 100 \mathrm{~g}$ sample [9]. Fish are considered good quality when the TBA value does not exceed $5 \mathrm{mg}$ malonaldehyde $/ \mathrm{kg}$ [10].

Sensory evaluation. The sensory evaluation of driedsmall fish $(3 \mathrm{~g})$ was done using 5 scale hedonic tests on each sample [11]. The scaling went from 1 - dislike very much, 2 - dislike a little , 3 - neither like nor dislike, 4 - like a little, and 5 - like very much to observe 5 parameters; color, aroma, taste, texture, and overall acceptance of small fish dried by sun, 60 and $80^{\circ} \mathrm{C}$ oven. This evaluation was conducted by 40 non-trained panelists consisting of students and staff members of the National Taiwan Ocean University, Keelung, Taiwan.

\subsection{Statistical Analysis}

All experiment data were analyzed with IBM SPSS Statistics 21 (IBM Corp, 2012). Comparison of values between muscle tissue and whole fish, and between oven- and sun-dried fish, were done using independent sample T-test analysis with 95\% confidence level. Changes of values during frozen storage and drying, also comparison between raw, $60^{\circ} \mathrm{C}$, and $80^{\circ} \mathrm{C}$ oven dried fish were analyzed using Duncan's Multiple Range Test as the post hoc's tool and significance level at $0.05 \quad(95 \%$ confidence).

\section{Results and Discussion}

\subsection{Proximate Composition of Bluestripe Herring}

The highest moisture content of entire bluestripe herring body was found in the smallest sized fish $(77.79 \%)$ while the lowest was found in the large sized fish $(71.58 \%)$ (Table 1). Ash content showed significant increase as the fish size increased $(p<0.05)$. The fat contents in small and medium fish were not significantly different but the large sized fish contained significantly higher amount of fat than the others $(p<0.05)$. Smaller-sized fish had significantly lower protein compared to the larger-sized. 
Table 1. Proximate composition of entire frozen Herklotsichthys quadrimaculatus body prepared as fishmeal in different size fish

\begin{tabular}{lccc}
\hline Proximate composition & Small & Medium & Large \\
\hline Moisture (\%) & $77.8 \pm 0.1^{\mathrm{a}}$ & $76.3 \pm 0.2^{\mathrm{b}}$ & $71.5 \pm 0.3^{\mathrm{c}}$ \\
Ash (\%) & $3.2 \pm 0.2^{\mathrm{a}}$ & $3.6 \pm 0.1^{\mathrm{b}}$ & $6.6 \pm 0.2^{\mathrm{c}}$ \\
Fat (\%) & $0.3 \pm 0.1^{\mathrm{a}}$ & $0.5 \pm 0.1^{\mathrm{a}}$ & $1.3 \pm 0.3^{\mathrm{b}}$ \\
Protein, N x 6.25(\%) & $12.4 \pm 0.1^{\mathrm{a}}$ & $13.3 \pm 0.2^{\mathrm{b}}$ & $14.3 \pm 0.1^{\mathrm{c}}$ \\
Carbohydrate (\%) & $6.4 \pm 0.2^{\mathrm{a}}$ & $6.3 \pm 0.3^{\mathrm{a}}$ & $6.2 \pm 0.6^{\mathrm{a}}$ \\
\hline
\end{tabular}

*The small fish was weighed 1-4 g, the medium fishwas weighed 5-13 g and caught in May 2014. The large fish was weighed over $14 \mathrm{~g}$ and caught in October 2014

**values in the same row followed by different letters are significantly different $(\mathrm{n}=3 ; p<0.05)$

Bluestripe herring's muscle tissue also showed similar moisture pattern with entire fish body where smaller-sized fish contained more moisture than the larger ones (Table 2). Both small- and large-sized fish had around $2 \%$ of ash while the medium one contained slightly higher ash content $(p<0.05)$. Fat content of bluestripe herring's muscle tissue fell at around $0.52-1.18 \%$, with significantly higher amount of fat $(p<0.05)$ in large-sized herring's muscle tissue compared to other sizes. The muscle tissue of all three sizes fish contained approximately 13-14\% of protein with no significant differences found among them.

Table 2. Proximate composition of frozen Herklotsichthys quadrimaculatus muscle tissue in different size fish

\begin{tabular}{lccc}
\hline Proximate composition & Small & Medium & Large \\
\hline Moisture (\%) & $77.8 \pm 0.2^{\mathrm{a}}$ & $76.2 \pm 0.3^{\mathrm{b}}$ & $74.3 \pm 0.3^{\mathrm{c}}$ \\
Ash (\%) & $2.0 \pm 0.1^{\mathrm{a}}$ & $2.3 \pm 0.1^{\mathrm{b}}$ & $2.1 \pm 0.1^{\mathrm{a}}$ \\
Fat (\%) & $0.5 \pm 0.1^{\mathrm{a}}$ & $0.6 \pm 0.1^{\mathrm{a}}$ & $1.2 \pm 0.2^{\mathrm{b}}$ \\
Protein, N x 6.25(\%) & $14.0 \pm 0.1^{\mathrm{a}}$ & $14.2 \pm 0.6^{\mathrm{a}}$ & $13.9 \pm 0.2^{\mathrm{a}}$ \\
Carbohydrate (\%) & $6.4 \pm 1.1^{\mathrm{a}}$ & $6.7 \pm 0.9^{\mathrm{a}}$ & $8.6 \pm 0.2^{\mathrm{b}}$ \\
\hline
\end{tabular}

*The small fish was weighed 1-4 g, the medium fishwas weighed 5-13 g and caught in May 2014. The large fish was weighed over $14 \mathrm{~g}$ and caught in October 2014.

**values in the same row followed by different letters are significantly different $(\mathrm{n}=3 ; p<0.05)$

The large-sized fish ( $>14 \mathrm{~g})$ contained the highest amount of calcium $(35,200 \mathrm{ppm})$, followed by small(30,052 ppm), and medium-sized fish (29,994 ppm) (Table 3). From independent T-test analysis, it was found that the ash content of entire small fish body was higher than of muscle tissue (Figure 1a). Both fat and protein contents in muscle tissue were higher than in entire fish body. Only ash content between entire medium fish body and medium fish's muscle tissue carried significant difference with the entire fish body containing higher amount of ash (Figure 1b). In large-sized fish, some obvious differences between proximate composition in muscle tissue and entire fish body were observed (Figure 1c). From all four parameters and moisture contents were higher in muscle tissue than in entire large fish body while ash and protein contents found in entire large fish body were higher than in muscle tissue.
Table 3. Calcium content of dried small, medium, and large Herklotsichthys quadrimaculatus

\begin{tabular}{lc}
\hline Sample & Calcium content (ppm) \\
\hline Small fish & 30,053 \\
Medium fish & 29,994 \\
Large fish & 35,200 \\
\hline
\end{tabular}

(a)

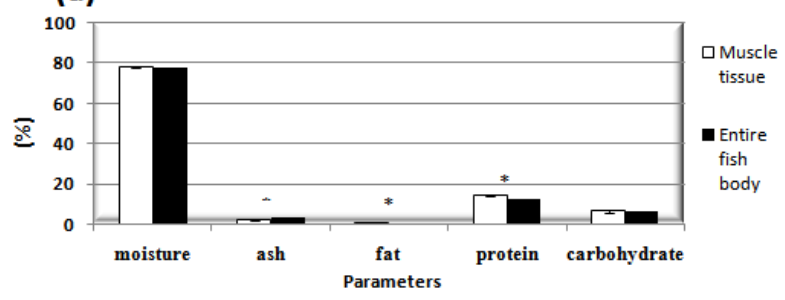

(b)

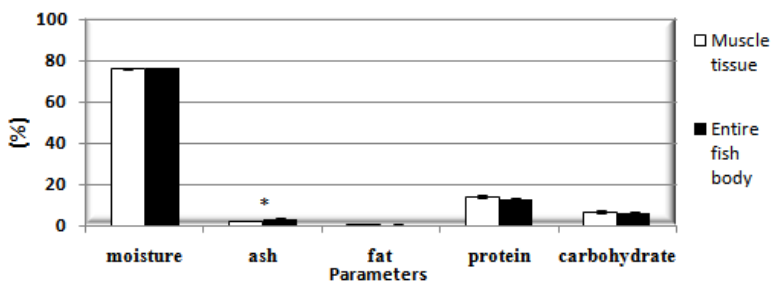

(c)

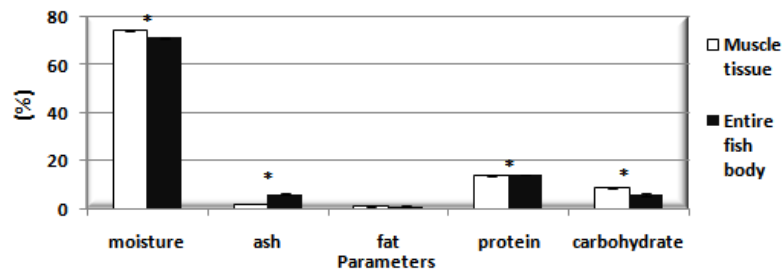

Figure 1. Comparison of proximate composition between muscle tissue andentire fish body of small (a), medium (b), and large-sized (c) Herklotsichthys quadrimaculatus. * in the same group marked with star (*) are significantly different $(\mathrm{n}=3 ; p<0.05)$

\subsubsection{Freshness Index Values During Chilled and Frozen Storage}

As shown in Table 4, the $\mathrm{pH}$ of entire small fish body was fluctuating during 6 months storage in $-20^{\circ} \mathrm{C}$ but a significant increase began after 5 months storage $(p<0.05)$. At 6 months storage, however, $\mathrm{pH}$ returned to 6.51 and fell around the initial level of the frozen fish's $\mathrm{pH}$. In Table 4, the $\mathrm{pH}$ of entire medium fish body did not show wide changes during $-20^{\circ} \mathrm{C}$ storage for 6 months. A significant increase began after 1 month storage and kept increasing to 6.69 at 2 months storage $(p<0.05)$ in large bluestripe herring. However, the $\mathrm{pH}$ of entire largefish body (Table 4) did not show any significant changes from the initial large frozen fish sample $(\mathrm{pH} 6.5)$ to the end of 6 months storage $(6.42)$ at $-20^{\circ} \mathrm{C}$.

TBA values of whole small fish showed significant increases throughout 6 months storage at $-20^{\circ} \mathrm{C}$ with highest value reached at the $3^{\text {rd }}$ month of storage (Figure 2a). The 1 week frozen fish contained $6.27 \mathrm{mg}$ malonaldehyde (MDA) $/ \mathrm{kg}$ and significantly increased $(p<0.05)$ to $11.04 \mathrm{mg} \mathrm{MDA} / \mathrm{kg}$ after 6 months frozen storage. TBA values of whole medium bluestripe herring (Figure 2b) also showed significant increase throughout 
6 months storage at $-20^{\circ} \mathrm{C}$ from $5.46 \mathrm{mg} \mathrm{MDA} / \mathrm{kg}$ to $20.98 \mathrm{mg} \mathrm{MDA} / \mathrm{kg}$ at the end of the storage. Compared to the TBA value of whole small bluestripe herring (11.04 $\mathrm{mg} \mathrm{MDA} / \mathrm{kg}$ ), the medium-sized contained much higher TBA at the end of storage $(20.98 \mathrm{mg} \mathrm{MDA} / \mathrm{kg})$. TBA values of whole large bluestripe herring (Figure 2c) seemed to be quite stable during the first 3 months of frozen storage $\left(-20^{\circ} \mathrm{C}\right)$ where the values from 0 to 2 month were not significantly different (7.77-9.08 $\mathrm{mg} \mathrm{MDA} / \mathrm{kg}$ sample) and slightly increased at the $3^{\text {rd }}$ month to $11.99 \mathrm{mg}$ MDA $/ \mathrm{kg}$. However, after 4 months storage, TBA value increased drastically to $32.05 \mathrm{mg} \mathrm{MDA} / \mathrm{kg}$ sample and reached its peak of $35.93 \mathrm{mg} \mathrm{MDA} / \mathrm{kg}$ sample at the $5^{\text {th }}$ month.

Table 4. pH changes of different entire Herklotsichthys quadrimaculatus body during $-20^{\circ} \mathrm{C}$ storage

\begin{tabular}{cccccccc}
\hline & \multicolumn{7}{c}{ Months } \\
\cline { 2 - 8 } $\begin{array}{c}\text { Fish } \\
\text { sizes }\end{array}$ & 0 & 1 & 2 & 3 & 4 & 5 & 6 \\
\hline \multirow{2}{*}{ Small } & $6.45 \pm$ & $6.4 \pm$ & $6.55 \pm$ & $6.47 \pm$ & $6.58 \pm$ & $6.63 \pm$ & $6.51 \pm$ \\
& $0.2^{\text {ab }}$ & $0.06^{\mathrm{a}}$ & $0.04^{\text {abc }}$ & $0.04^{\text {abc }}$ & $0.07^{\text {bc }}$ & $0.06^{\mathrm{c}}$ & $0.03^{\text {abc }}$ \\
Medi & $6.52 \pm$ & $6.41 \pm$ & $6.52 \pm$ & $6.54 \pm$ & $6.57 \pm$ & $6.48 \pm$ & $6.49 \pm$ \\
um & $0.07^{\text {bdd }}$ & $0.04^{\mathrm{a}}$ & $0.03^{\text {bcd }}$ & $0.02^{\text {cd }}$ & $0.03^{\mathrm{d}}$ & $0.02^{\mathrm{b}}$ & $0.02^{\text {bc }}$ \\
& $6.5 \pm$ & $6.65 \pm$ & $6.69 \pm$ & $6.61 \pm$ & $6.42 \pm$ & $6.32 \pm$ & $6.42 \pm$ \\
Large & $6.0 .07^{\mathrm{b}}$ & $0.01^{\text {cd }}$ & $0.02^{\mathrm{d}}$ & $0.05^{\mathrm{c}}$ & $0.05^{\mathrm{b}}$ & $0.03^{\mathrm{a}}$ & $0.07^{\mathrm{b}}$ \\
\hline
\end{tabular}

*The small fish was weighed 1-4 g, the medium fishwas weighed 5-13 g and caught in May 2014. The large fish was weighed over $14 \mathrm{~g}$ and caught in October 2014.

**values in the same row followed by different letters are significantly different $(\mathrm{n}=3 ; p<0.05)$

(a)

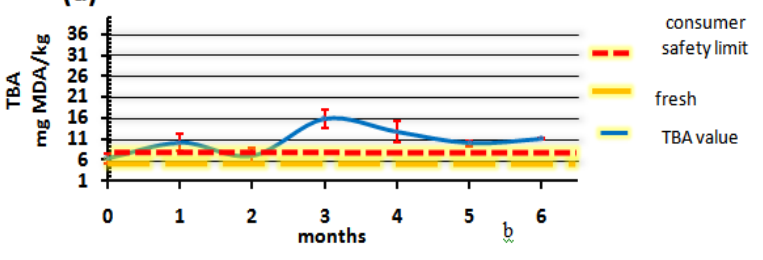

(b)

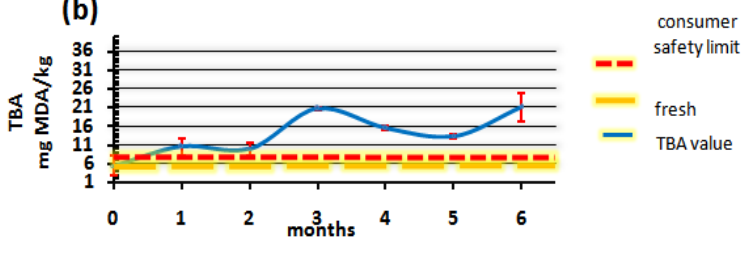

(c)

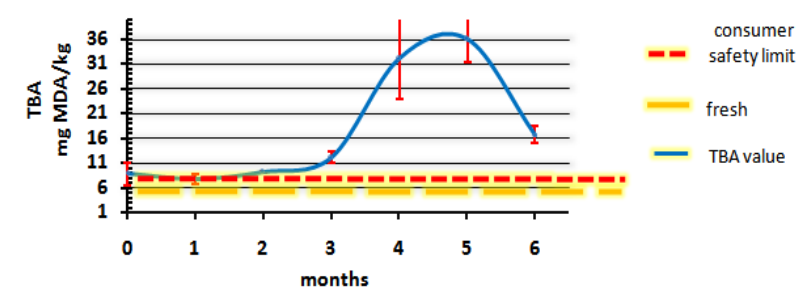

Figure 2. Changes of TBA value in small- (a), medium- (b), and bigsized (c) Herklotsichthys quadrimaculatus during frozen storage $(\mathrm{n}=3)$.

In Figure $3 \mathrm{a}$, the TVBN values of small bluestripe herring during 6 months storage in $-20^{\circ} \mathrm{C}$ seemed to be fluctuating at around 11.1-15.84 mg N/100 g sample. Throughout the storage period, the small fish reached highest TVBN value after being stored for 3 months. However, after the $3^{\text {rd }}$ month, the TVBN values returned to the level of fresh fish. Similarly, the TVBN values of medium bluestripe herring (Figure $3 \mathrm{~b}$ ) also seemed to increase significantly after 3 months storage in $-20^{\circ} \mathrm{C}$. After reaching the highest TVBN value at the $3^{\text {rd }}$ month (17.27 mg N/100 g sample), it fell back to initial TVBN range of the frozen fish at the $4^{\text {th }}$ month and kept on decreasing throughout the $6^{\text {th }}$ month to only around 11.36 $\mathrm{mg} \mathrm{N} / 100 \mathrm{~g}$ sample. TVBN value of whole large bluestripe herring (Figure 3c) ranged from 8.4 to $13.41 \mathrm{mg}$ $\mathrm{N} / 100 \mathrm{~g}$ sample with the highest value reached after 5 month storage. Unlike small and medium bluestripe herring, the large-sized bluestripe herring's TVBN values went down during the first three months of frozen storage $\left(-20^{\circ} \mathrm{C}\right)$ then increase to $5^{\text {th }}$ month and started to drop back to $11.18 \mathrm{mg} \mathrm{N} / 100 \mathrm{~g}$ at the $6^{\text {th }}$ month.

(a)

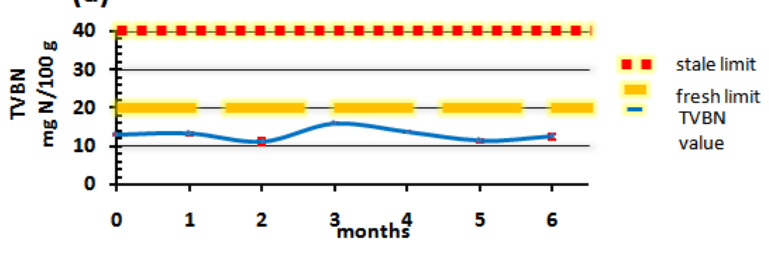

(b)

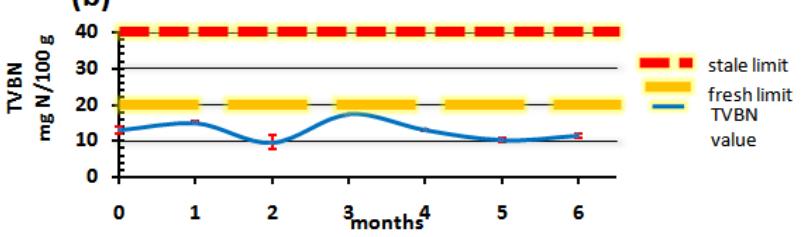

(c)

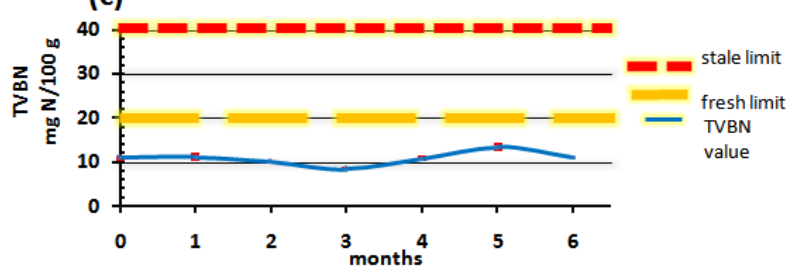

Figure 3. Changes of TVBN value in small- (a), medium- (b), and bigsized (c) Herklotsichthys quadrimaculatusduring frozen storage $(\mathrm{n}=3)$

The TVBN value in muscle tissue was found to be significantly higher than in all sized whole fish $(p<0.05)$ (Figure 4). All freshness index values $(\mathrm{pH}, \mathrm{TVBN}$, and TBA) between entire medium fish and medium fish muscle tissue after 6 months storage in $-20^{\circ} \mathrm{C}$ (Figure $4 \mathrm{~b}$ ) were proven to be statistically different $(p<0.05) . \mathrm{pH}$ of whole medium bluestripe herring was statistically higher than that in the flesh part $(p<0.05)$. Similar to small- and large-sized bluestripe herring, TVBN value in the flesh of medium-sized bluestripe herring was higher than in the whole medium fish. The TBA value in whole mediumsized fish (20.98 mg MDA/ $\mathrm{kg}$ ) was more than two folds of the value contained in the flesh part $(9.63 \mathrm{mg} \mathrm{MDA} / \mathrm{kg})$. Despite of TBA value, both $\mathrm{pH}$ and TVBN values between flesh and whole large fish stored in $-20^{\circ} \mathrm{C}$ for 6 months were statistically different (Figure $4 \mathrm{c}$ ). $\mathrm{pH}$ of whole large bluestripe herring was significantly higher than in the flesh of large-sized herring while the TVBN 
value of flesh part was higher than in whole large bluestripe herring.
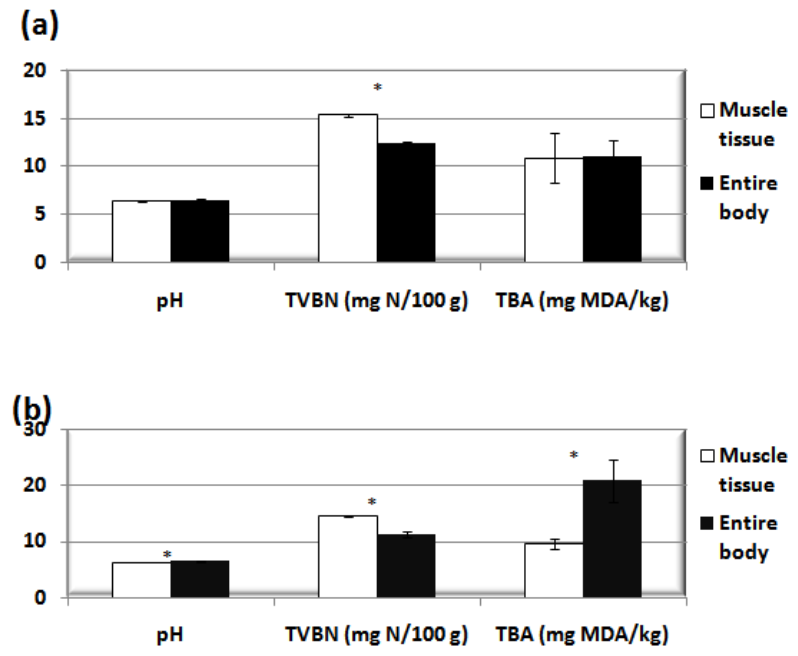

(c)

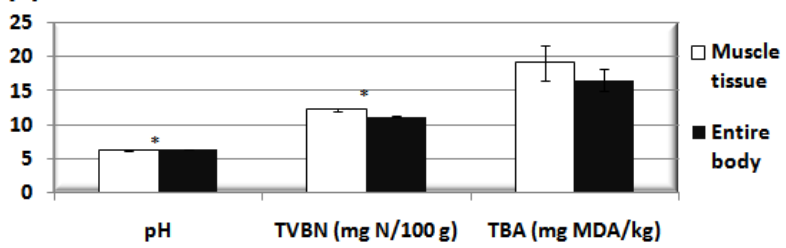

Figure 4. Values comparison of muscle tissue and entire body in small(a), medium- (b), and big-sized (c) Herklotsichthys quadrimaculatus after 6 months frozen storage. *values in the same group marked with star $(*)$ are significantly different $(\mathrm{n}=3 ; p<0.05)$

\subsubsection{Small Fish Drying Process and Quality}

In Table 5, pH, TVBN and TBA values of sun-dried fish was found to be significantly higher than that of the oven dried fish $(p<0.05)$. The freshness index values of $\mathrm{pH}$ and TVBN between fish dried at $60^{\circ} \mathrm{C}$ and $80^{\circ} \mathrm{C}$ were not significantly different (Table 5). However, both ovendried fish had significantly lower $\mathrm{pH}$ and higher TVBN and TBA values compared to the frozen small fish for 1 week $(p<0.05)$.

Table 5. Values comparison between small Herklotsichthys quadrimaculatus dried in $60^{\circ} \mathrm{C}, 80^{\circ} \mathrm{C}$, dun-dried and frozen for 1 week fish prepared as freshmeal

\begin{tabular}{lcccc}
\hline Parameters & $\begin{array}{c}\text { Sun } \\
\text { dried }\end{array}$ & $\begin{array}{c}60^{\circ} \mathrm{C} \text { oven } \\
\text { dried }\end{array}$ & $\begin{array}{c}80^{\circ} \mathrm{C} \text { oven } \\
\text { dried }\end{array}$ & $\begin{array}{c}\text { Frozen for 1 } \\
\text { week }\end{array}$ \\
\hline $\mathrm{pH}$ & $6.4^{\mathrm{a}}$ & $6.3^{\mathrm{b}}$ & $6.3^{\mathrm{b}}$ & $6.4^{\mathrm{a}}$ \\
$\mathrm{TVBN}(\mathrm{mg} \mathrm{N} / 100 \mathrm{~g})$ & $20^{\mathrm{c}}$ & $17.1^{\mathrm{b}}$ & $16.4^{\mathrm{b}}$ & $11.2^{\mathrm{a}}$ \\
TBA (mg MDA $/ \mathrm{kg})$ & $89.5^{\mathrm{d}}$ & $74.9^{\mathrm{c}}$ & $59.5^{\mathrm{b}}$ & $15.4^{\mathrm{a}}$ \\
\hline
\end{tabular}

*The small fish was weighed 1-4 g and caught in May 2014.

$* *$ values in the same row followed by different letters are significantly different $(\mathrm{n}=3 ; p<0.05)$

During $60^{\circ} \mathrm{C}$ oven drying, the moisture content of small-sized bluestripe herring dropped from $74.10 \%$ to $5.77 \%$ (Figure $5 \mathrm{~b}$ ). The water activity $\left(\mathrm{a}_{\mathrm{w}}\right)$ of small bluestripe herring decreased from 0.98 to 0.23 during $14 \mathrm{~h}$ oven dying at $60^{\circ} \mathrm{C}$ (Figure 5a). Meanwhile, at $80^{\circ} \mathrm{C}$, the moisture content of small fish fell from $76.65 \%$ to $3.23 \%$ (Figure 6b) and water activity from 0.97 to 0.11 during 10 $\mathrm{h}$ of drying (Figure 6a). As seen in Figure 7, the sun drying process of small bluestripe herring took much longer time than oven drying. To reach the lowest water activity of 0.4 , the fish needed to be dried for around $34 \mathrm{~h}$. After $42 \mathrm{~h}$ drying, the $\mathrm{a}_{\mathrm{w}}$ returned to 0.56 (Figure 7).

In Table 6 , the acceptance levels of the sensory properties between sun dried, $60^{\circ} \mathrm{C}$, and $80^{\circ} \mathrm{C}$ oven dried fish among 40 panelists were shown. The color acceptance level fell under 'neither like nor dislike' category with no significant difference found between the three samples. The aroma acceptance of $80^{\circ} \mathrm{C}$-oven-dried fish was significantly higher $(p<0.05)$ than both sun dried and $60^{\circ} \mathrm{C}$ oven dried fish (which were in the same category of neither like nor dislike). The taste of both $60^{\circ} \mathrm{C}$ and $80^{\circ} \mathrm{C}$ oven dried fish were proven to be more preferable than the taste of sun dried fish. Texture of $80^{\circ} \mathrm{C}$ oven dried fish was the most well accepted among panelists, followed by $60^{\circ} \mathrm{C}$ oven dried and sun dried fish. The overall acceptance levels of oven dried fish (both $60^{\circ} \mathrm{C}$ and $80^{\circ} \mathrm{C}$ ) were significantly higher than that of sun dried fish $(p<0.05)$.
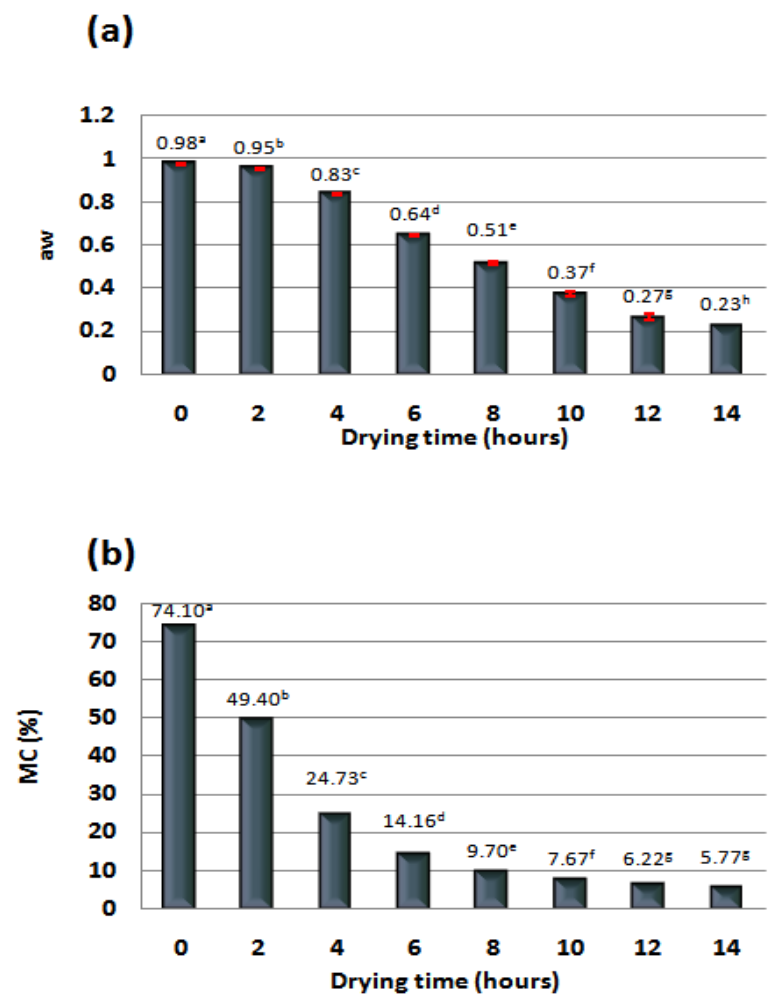

Figure 5. Changes of $a_{w}$ (a) and moisture content (b) of small-sized Herklotsichthys quadrimaculatus during oven drying at $60^{\circ} \mathrm{C}$. *values followed by different letters are significantly different $(\mathrm{n}=3 ; p<0.05)$

Table 6. Hedonic sensory properties of small Herklotsichthys quadrimaculatus dried with oven and under sun

\begin{tabular}{cccc}
\hline Sensory parameter & Sun dried & $60^{\circ} \mathrm{C}$ oven dried & $80^{\circ} \mathrm{C}$ oven dried \\
\hline Color & $3.28 \pm 1.15^{\mathrm{a}}$ & $3.28 \pm 0.75^{\mathrm{a}}$ & $2.95 \pm 0.90^{\mathrm{a}}$ \\
Aroma & $2.73 \pm 1.01^{\mathrm{a}}$ & $3.08 \pm 0.66^{\mathrm{a}}$ & $3.60 \pm 0.98^{\mathrm{b}}$ \\
Taste & $2.53 \pm 0.85^{\mathrm{a}}$ & $3.10 \pm 0.96^{\mathrm{b}}$ & $3.18 \pm 1.13^{\mathrm{b}}$ \\
Texture & $2.45 \pm 1.20^{\mathrm{a}}$ & $2.73 \pm 0.88^{\mathrm{ab}}$ & $3.05 \pm 0.85^{\mathrm{b}}$ \\
Overall acceptance & $2.40 \pm 0.90^{\mathrm{a}}$ & $3.03 \pm 0.80^{\mathrm{b}}$ & $3.23 \pm 0.92^{\mathrm{b}}$ \\
\hline
\end{tabular}

Scale for evaluation for each of the parameters: 1 - dislike very much, 2 - dislike a little , 3 - neither like nor dislike, 4 - like a little, and 5 - like very much

* values in the same row followed by different letters are significantly different $(\mathrm{n}=40 ; p<0.05)$ 
(a)
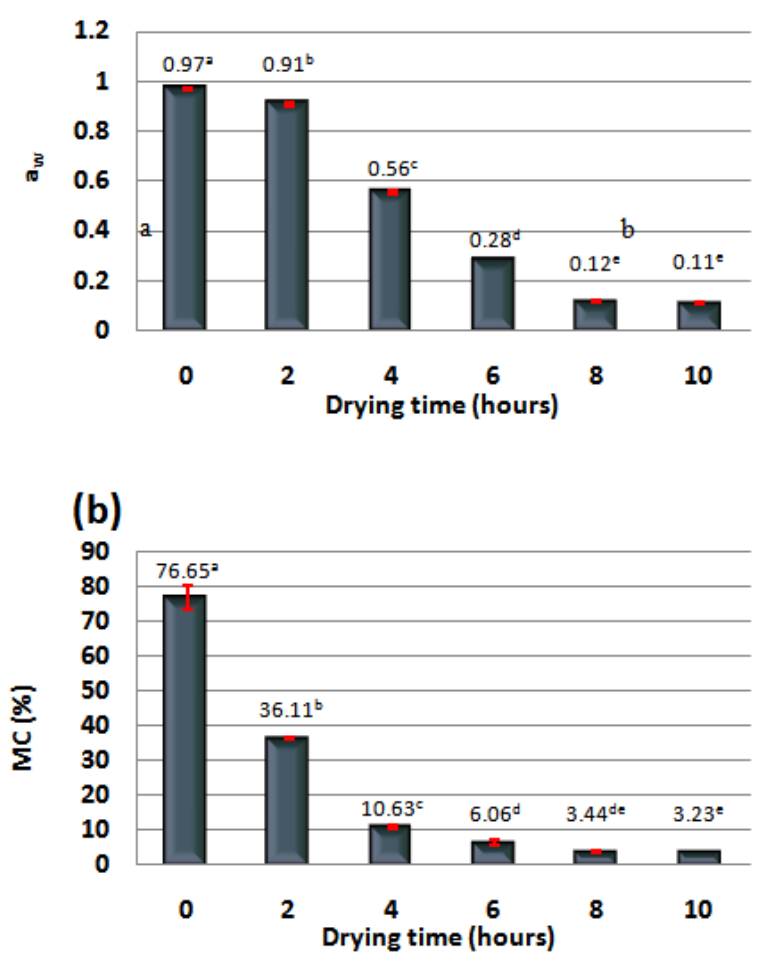

Figure 6. Changes of $a_{w}$ (a) and moisture content (b) of small-sized Herklotsichthys quadrimaculatus during oven drying at $80^{\circ} \mathrm{C}$. *values followed by different letters are significantly different $(\mathrm{n}=3 ; p<0.05)$

\section{(a)}

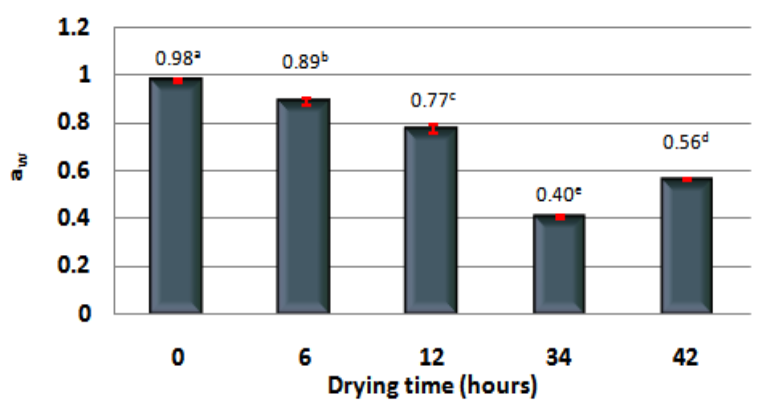

(b)

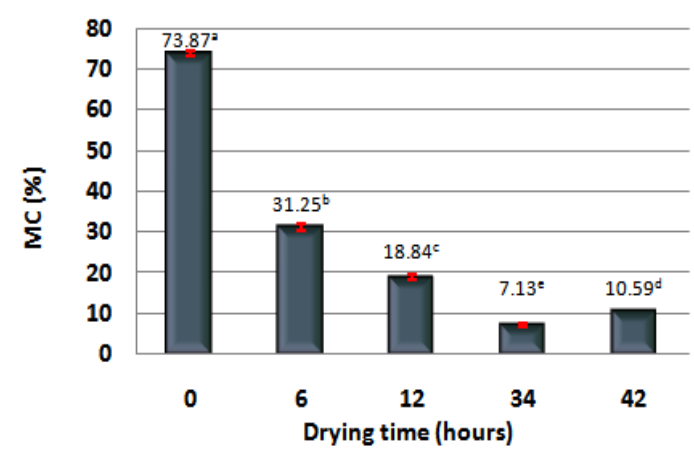

Figure 7. Changes of $a_{w}$ (a) and moisture content (b) of small-sized Herklotsichthys quadrimaculatus during sun drying. *values followed by different letters are significantly different $(\mathrm{n}=3 ; p<0.05)$

\section{Conclusion}

The proximate composition in fish was influenced by the size. Smaller-sizes entire fish body contained more water while the larger ones contained higher ash, fat, protein, and calcium. The significantly higher amount of ash in whole fish compared to muscle tissue indicated that the minerals were deposited in other parts except flesh. This finding suggested the benefit of utilizing small-sized bluestripe herring for human consumption as it is commonly processed and eaten as whole. $\mathrm{pH}$ and TVBN values indicate that bluestripe herring (all sizes) were still in fresh condition even after 6 months storage at $-20^{\circ} \mathrm{C}$, but considering the TBA values, the fish were considered best to process or consume when fresh or at most before 1 month at $-20^{\circ} \mathrm{C}$ frozen storage. Drying in oven at $80^{\circ} \mathrm{C}$ was found to be more effective than at $60^{\circ} \mathrm{C}$ as it only takes half of the time ( 4 hours) needed to dry the fish at $60^{\circ} \mathrm{C}$. The $\mathrm{pH}$ and TVBN values also indicated no significant difference between the fish dried in oven at $60^{\circ} \mathrm{C}$ and $80^{\circ} \mathrm{C}$. As to the sun dried fish, the fish ovendried at $80^{\circ} \mathrm{C}$ seemed to have lower amount of TVBN. Both, however, were still considered suitable for human consumption. Furthermore, the sensory analysis result also suggested that oven dried fish had better acceptance level among the test panelists. Regarding to the convenience, sensory acceptance level, and time saving benefits, oven drying the fish at $80^{\circ} \mathrm{C}$ deserves to be considered an as alternative to traditional sun drying method.

\section{References}

[1] Thomas RC, Beldia PD, Campos WL, Santos MD. Gene pool and population structure in larval Herklotsichthys quadrimaculatus (Rüppell, 1837). J Appl Ichthyol 30: 1031-1034, 2014.

[2] Valdivia P, Isabal S. Studied for preservation of sardine in brine. Memoirs of the Faculty of Fisheries Hokkaido University 41: 1-104, 1994.

[3] Mallikage M. The effect of different cooling systems on quality of pelagic species (Final project). The United Nations University, Reykjavik, IS, 2001.

[4] Larsen T, Thilsted SH, Kongsbak K, Hansen M. Whole small fish as a rich calcium source. Br J Nutr 83: 191-196, 2000.

[5] AOAC. Official Methods of Analysis of the Association of Official Analytical Chemists. 16th ed. Sidney W (eds) Washington D.C., USA, 1998.

[6] Cobb BF, Alaniz I, Thompson CA. Biochemical and microbial studies on shrimp: volatile nitrogen and amino nitrogen analysis. $J$ Food Sci 38: 431-436, 1973.

[7] Vyncke W. Evaluation of the Direct Thiobarbituric Acid Extraction Method for Determining Oxidative Rancidity in Mackerel (Scomber scombrus L.). Fette, Seifen, Anstrichmittel 77: 239-240, 1975.

[8] Konosu S, Watanabe K, Shimizu T. Distribution of nitrogenous constituents in the muscle extracts of eight species of fish. Nippon Suisan Gakkai Shi 40: 909-915, 1974.

[9] Egan H, Kirk RS, Sawyer R. Pearson's Chemical Analyses of Foods. $8^{\text {th }}$ ed. London: Longman Scientific Publish. 609-634, 1981.

[10] Orak HH, Kayisoglu S. Quality changes in whole, gutted, and filleted three fish species (Gadus euxinus, Mugil cephalus, Engraulis encrasicholus) at frozen storage period $\left(-26^{\circ} \mathrm{C}\right)$. Acta Scientiarum Polonorum, Technologia Alimentaria 7: 15-28, 2008.

[11] Birch GG, Brennan JG, Parker KJ. (Eds.). Sensory properties of foods. England, UK: Applied Science Publishers LTD, 1977. 